\title{
Supplementary Material for \\ EXPLOITING HIS-TAGS FOR ABSOLUTE QUANTITATION OF EXOGENOUS RECOMBINANT PROTEINS IN BIOLOGICAL MATRICES: RUTHENIUM AS A PROTEIN TRACER
}

Chengfeng Ren, Cedric E. Bobst and Igor A. Kaltashov*

Department of Chemistry, University of Massachusetts-Amherst, Amherst, MA 01003

Email: kaltashov@chem.umass.edu

\section{Table of Contents:}

Figure S1. An ESI mass spectrum of the model peptide incubated with $\left[\mathrm{Ru}\left(\mathrm{NH}_{3}\right)_{5} \mathrm{Cl}\right] \mathrm{Cl}$ in ammonium bicarbonate ( $\mathrm{pH} 8$ ) under unaerobic conditions for 48 hours followed by air oxidation. The zoomed view of the peptide/metal complex (inset) shows isotopic distribution consistent with the notion of an oxidized metal $\left(\mathrm{Ru}^{\mathrm{III}}\right)$ bound to the peptide.

Figure S2. A mass spectrum of fragment ions produced by electron-capture dissociation of ESIgenerated $\left[\mathrm{Ru}^{\mathrm{III}} \mathrm{T}_{2} \mathrm{M}+2 \mathrm{H}\right]^{5+}$.

Figure S3. An amino acid sequence (top) and a three-dimensional structure (bottom) of human serum transferrin. The wild-type sequence is shown in black, and the N-terminal His-tag segment of the recombinant protein is shown in blue. All histidine residues are highlighted in cyan. 


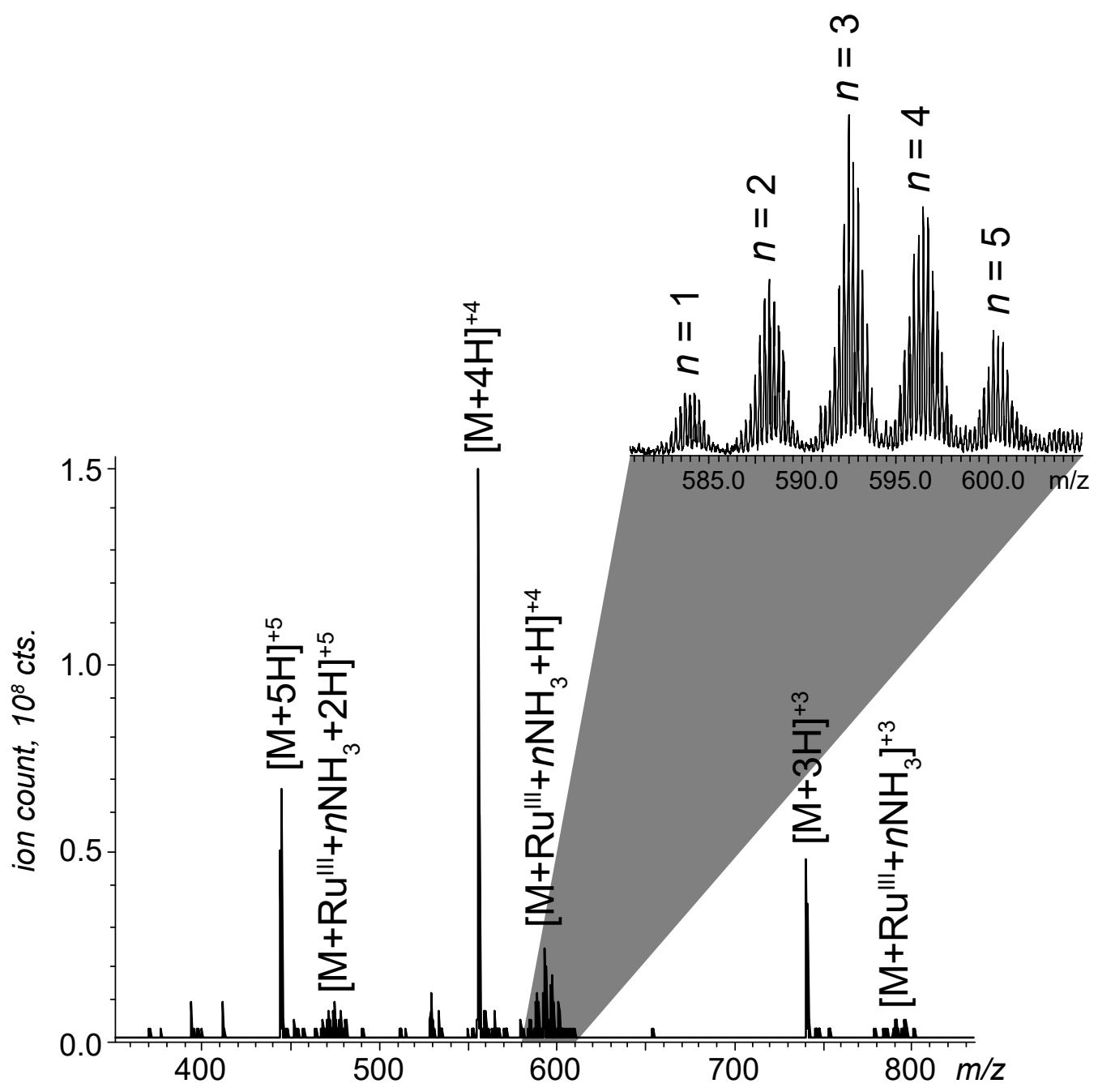

Figure S1. An ESI mass spectrum of the model peptide incubated with [Ru(NH3)5Cl]Cl in ammonium bicarbonate $(\mathrm{pH} 8)$ under unaerobic conditions for 48 hours followed by air oxidation. The zoomed view of the peptide/metal complex (inset) shows isotopic distribution consistent with the notion of an oxidized metal (RullI) bound to the peptide. 

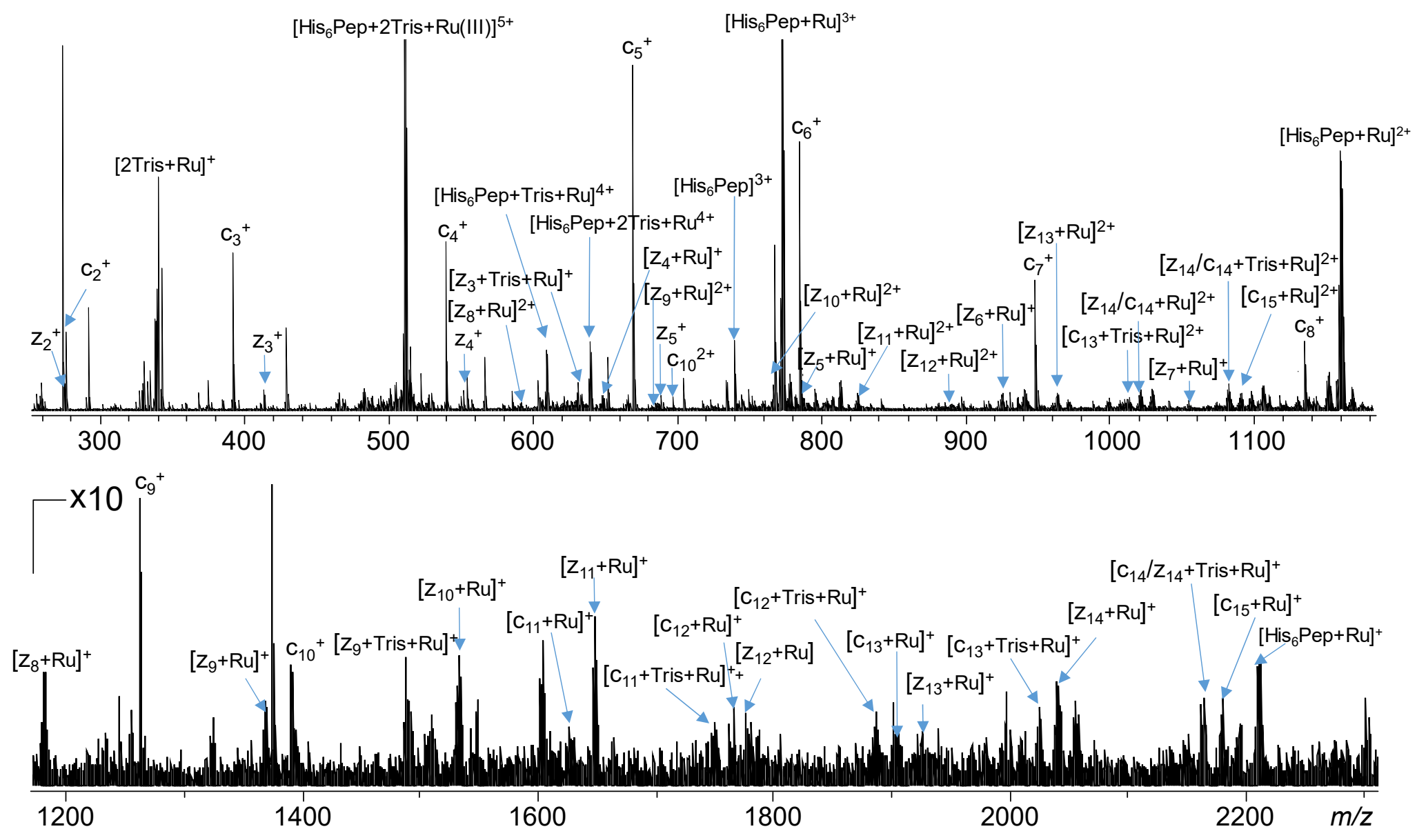

Figure S2. A mass spectrum of fragment ions produced by electron-capture dissociation of ESI-generated [RullIT2M + 2H]5+. 
VPDKHHHHHH IEGRVPDKTV RWCAVSEHEA TKCQSFRDHM KSVIPSDGPS VACVKKASYL DCIRAIAANE ADAVTLDAGL VYDAYLAPNN LKPVVAEFYG SKEDPQTFYY AVAVVKKDSG FQMNQLRGKK SCHTGLGRSA GWNIPIGLLY CDLPEPRKPL EKAVANFFSG SCAPCADGTD FPQLCQLCPG CGCSTLNQYF GYSGAFKCLK DGAGDVAFVK HSTIFENLAN KADRDQYELL CLDNTRKPVD EYKDCHLAQV PSHTVVARSM GGKEDLIWEL LNQAQEHFGK DKSKEFQLFS SPHGKDLLFK DSAHGFLKVP PRMDAKMYLG YEYVTAIRNL REGTCPEAPT DECKPVKWCA LSHHERLKCD EWSVNSVGKI ECVSAETTED CIAKIMNGEA DAMSLDGGFV YIAGKCGLVP VLAENYDKSD NCEDTPEAGY FAVAVVKKSA SDLTWDNLKG KKSCHTAVGR TAGWNIPMGL LYNKINHCRF DEFFSEGCAP GSKKDSSLCK LCMGSGLNLC EPNNKEGYYG YTGAFRCLVE KGDVAFVKHQ TVPQNTGGKN PDPWAKNLNE KDYELLCLDG TRKPVEEYAN CHLARAPNHA VVTRKDKEAC VHKILRQQQH LFGSDVTDCS GNFCLFRSET KDLLFRDDTV CLAKLHDRNT YEKYLGEEYV KAVGNLRKCS TSSLLEACTF RRP

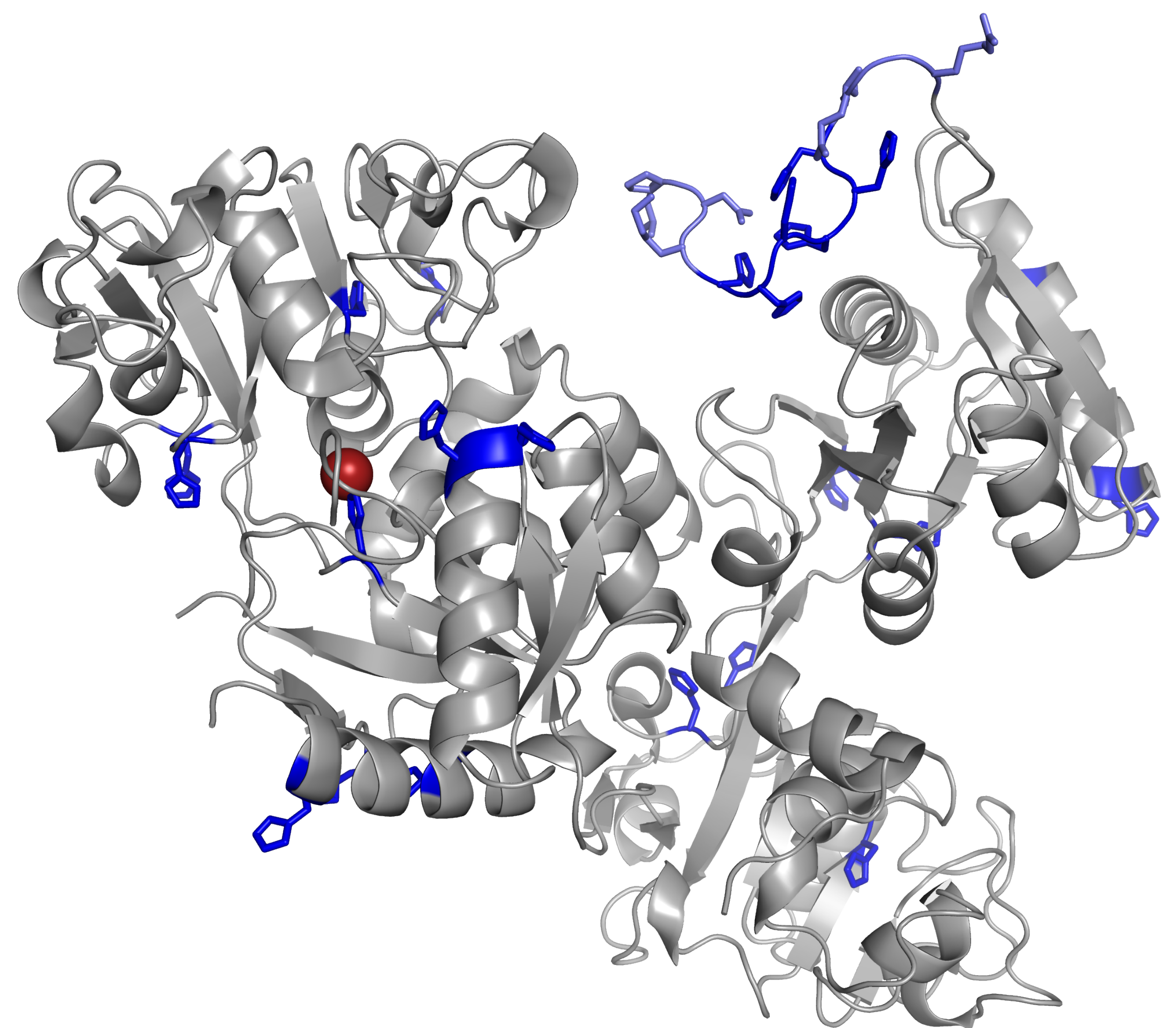

Figure S3. An amino acid sequence (top) and a three-dimensional structure (bottom) of human serum transferrin. The wild-type sequence is shown in black, and the N-terminal His-tag segment of the recombinant protein is shown in blue. All histidine residues are highlighted in cyan. 